POLICE OFFICERS' ATTITUDES TOWARD CITIZENS IN CHINA

by

Lin Liu

A thesis submitted to the Faculty of the University of Delaware in partial fulfillment of the requirements for the degree of Master of Arts in Criminology

Spring 2016

(C) 2016 Lin Liu

All Rights Reserved 
Pro Quest Number: 10157390

All rights reserved

INFORMATION TO ALL USERS

The quality of this reproduction is dependent upon the quality of the copy submitted.

In the unlikely event that the authordid not send a complete manuscript and there are missing pages, the se will be noted. Also, if material had to be removed, a note will indicate the deletion.

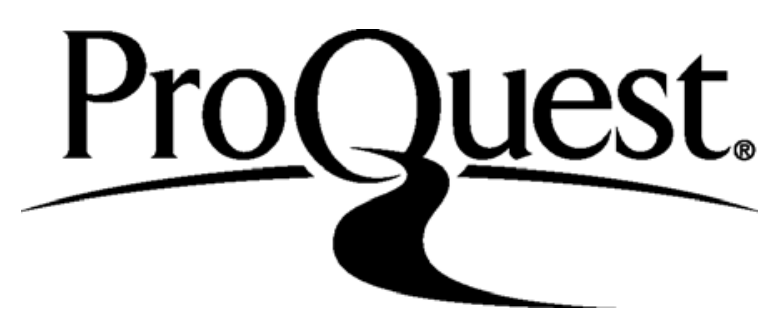

Pro Quest 10157390

Published by Pro Quest LLC (2016). Copyright of the Dissertation is held by the Author.

All rights re served.

This work is protected against unauthorized copying under Title 17, United States Code Mic ro form Edition () Pro Que st $\amalg C$.

Pro Quest LLC.

789 East Eisenhower Parkway

P.O. Box 1346

Ann Arbor, MI 48106 - 1346 


\title{
POLICE OFFICERS' ATTITUDES TOWARD CITIZENS IN CHINA
}

\author{
by
}

Lin Liu

Approved:

Ivan Sun, Ph.D.

Professor in charge of thesis on behalf of the Advisory Committee

Approved:

Kirk R. Williams, Ph.D.

Chair of the Department of Sociology and Criminal Justice

Approved:

George H. Watson, Ph.D.

Dean of the College of Arts \& Sciences

Approved:

Ann L. Ardis, Ph.D.

Senior Vice Provost for Graduate and Professional Education 


\section{ACKNOWLEDGMENTS}

The completion of this thesis would not have been possible without the close supervision of my advisor, Dr. Ivan Sun, and my thesis committee members Dr. Susan Miller and Dr. Eric Rise. Constructive advices given by my committee members during my thesis proposal defense in last semester have significantly contributed to the improvement of earlier drafts of this thesis. My gratitude also goes to my informant from a police department who offered insightful information on this topic. Last but not least, I thank my fellow graduate students who offered encouragement and support during the process of my research and writing. 


\section{TABLE OF CONTENTS}

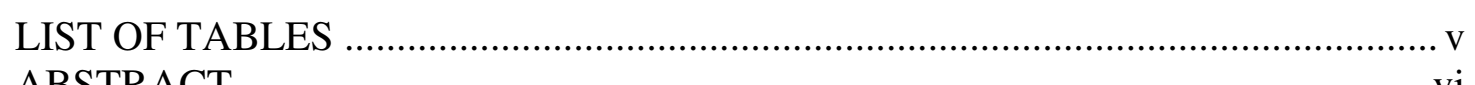

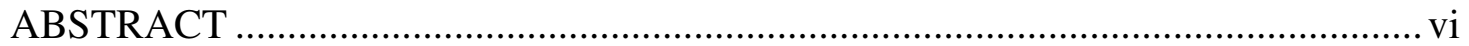

Chapter

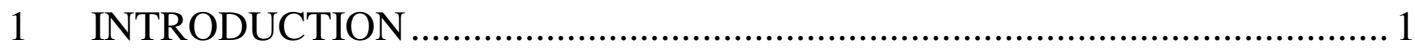

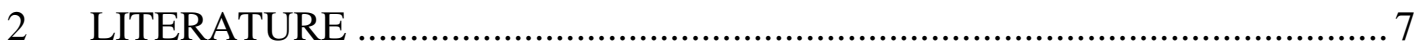

Recent Developments in Chinese Policing.................................................. 7

Police Officers' Attitudes Toward Citizens ................................................. 14

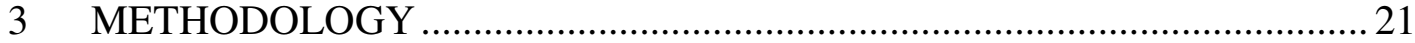

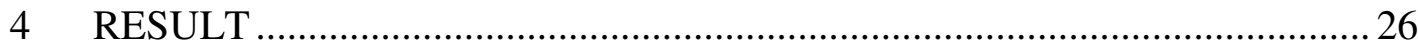

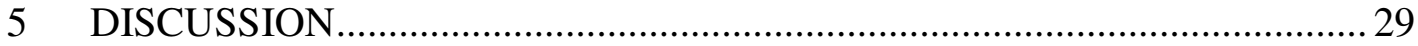

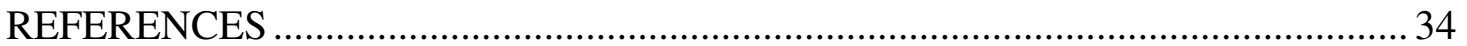




\section{LIST OF TABLES}

Table 1 Descriptive Statistics for Variables in Regression Analysis $(n=210) \ldots . .23$

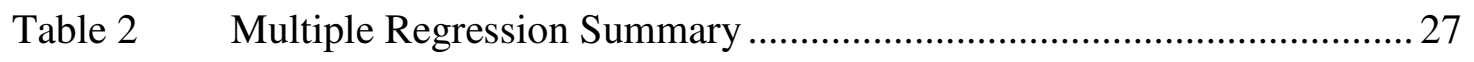




\begin{abstract}
Although a substantial number of studies have examined public attitudes toward the police, a relatively thin line of research has assessed police attitudes toward the citizenry. Using survey data collected from a sample of approximately 200 Chinese police officers, the current study examined the effects of police officers' demographic characteristics, socialization/experiences factors, and role orientations on officers' attitudes toward trust in citizens, citizens' cooperation with the police, citizens' appreciation of police work, citizens' input in police work, and citizens' virtue. Results indicated that background and experience characteristics were ineffective in predicting five aspects of officer attitudes toward citizens. Role orientations were first found to be related to multiple dimensions on officers' attitudes toward the citizenry. Findings of this study enhance our understanding of police occupational attitudes in China and provide valuable implications for policy and future research.
\end{abstract}




\section{Chapter 1}

\section{INTRODUCTION}

The police and citizen relationship is one of the most important elements in modern policing (Brandl, Frank, Wooldredge \& Watkins, 1997; Cao \& Stack, 2005; Carter \& Radelet, 2002; Correia, 2000; Frank, Brandl \& Watkins, 1997; Hu \& Dai, 2014; Jiang, Lambert, Liu, \& Saito, 2014; Lurigio \& Skogan, 1994; Wu, Sun, \& Triplett, 2009). As the most visible symbol of governmental authority (Gabbidon \& Greene, 2012), the police have been subjected to a substantial amount of research. One main line of such inquiries examined the effects of citizen background characteristics, crime and justice experiences, social attitudes and neighborhood conditions on attitudes toward the police (Brandl et al., 1994; Cao \& Stack, 2005; Hu \& Dai, 2014; Jiang et al., 2014; Macdonald \& Stokes, 2006; Scaglion \& Condon, 1980; Skogan, 1978). However, a comparatively smaller body of research has analyzed factors influencing police officers' attitudes toward citizens (Brooks, Piquero \& Cronin,, 1993; Chen, 2016; Chu \& Sun, 2007; DeJong, 2004; Haarr, 2001; He, Zhao, \& Ren, 2005; Ingram \& Terrill, 2014; Paoline, Myers, \& Worden, 2000; Phillips, 2015; Sun, 2002; Worden, 1993).

Police attitudes toward citizenry not only impact police-community relations and public trust in and cooperation with the police, but also influence how officers treat citizens in micro level police and citizen interactions (Worden, 1996). Recent deadly incidents in Ferguson, New York City, and Baltimore elucidated the sensitivity and complexity of citizens-police confrontations involving the use (or misuse in most 
cases) of police authority and power (Brandl, Frank, Worden, \& Bynum 1994; Gau \& Brunson, 2015; Brown \& Langan, 2001; Lasley, 1994; McCluskey, Mastrofski, \& Parks, 1999; Paternoster, Brame, Bachman, \& Sherman, 1997; Qi \& Oberwittler, 2009; Reisig \& Parks, 2000; Stone \& Pettigrew, 2000; Tuch \& Weitzer, 1997; Tyler \& Wakslak, 2004), highlighting the importance to examine police attitude towards citizenry.

Specifically, there are several reasons to study officers' attitudes toward citizens from various perspectives including officers' work efficiency and promotion, peer acknowledgement, and citizens' experience in the police-citizen encounters. First, police officers' attitudes toward citizens affect their efficacy in collecting information from the public. Negative attitudes toward the public might lower officers' motivation to contact citizens, resulting in a smaller base of information resource and poor criminal prevention and investigation. Indeed, local residents know much better about their neighborhoods than the police, and police officers have to rely on their "insider" information to control crime, arrest suspects and solve problems (Jiao, 1998, 2001; Reisig, 2007; Skogan, 1999; Tyler, 2006; Wang \& Wong, 2012; Wilson \& Kelling, 2007).

Second and even more importantly, police officers' attitudes toward the public may influence how citizens are treated during interactions. Unfavorable opinion on citizens would lead police to treat citizens in an unfriendly, hostile, or even brutal way (Brandl, Stroshine \& Frank, 2001; Chevigny, 1969; Freidrich, 1980; Holmes, Reynolds, Holmes, \& Faulkner 1998; Liska \& Yu, 1992; Smith \& Holmes, 2003, 2014; Wong, 1998). Such treatment would definitely carve a bad image of police among the public and discourage citizens from cooperate with the police, leading 
police-citizens relationship into a malicious circle (Goldsmith, 2005; Murphy \& Cherney, 2011; Weitzer \& Brunson, 2009).

Finally, how officers perceive citizens could shape how they indoctrinate the modern police occupational roles of service and problem solving into their subjective attitudinal orientations. If an officer possesses negative attitudes toward citizens, he or she might choose to intentionally ignore the roles of service and order maintenance and heavily endorse law enforcement and crime fighting instead. Such inconsistency between individual officers' role orientations and the collective policing strategies (e.g., community- and problem-oriented policing) could cause poor work performance and block the officer from getting rewards, promotions and peer acknowledgements (Beehr, Johnson \& Nieva, 1995; Engel \& Worden, 2003; Ingram, 2013; Skogan \& Hartnett, 1997; Wang \& Wong, 2012; Wycoff \& Skogan, 1994).

The main purpose of this study is to unravel the relationship between the Chinese police and citizens from police officers' perspectives by assessing factors affecting their attitudes toward citizens. While some studies have investigated police attitudes toward citizens in the U.S (Brooks et al., 1993; DeJong, 2004; Haarr, 2001; He et al., 2005; Ingram \& Terrill, 2014; Paoline et al., 2000; Phillips, 2015; Sun, 2002; Worden, 1993), such research is virtually non-existent in China. To date, only a handful of studies have examined Chinese police occupational outlook, such as their cynicism, role orientations and support for community building (Chen, 2016; Cuvelier, Jia, \& Jin., 2015; Sun, Cretacci, Wu, \& Jin 2009; Sun, Liu, \& Farmer, 2016; Sun, Sobol, Cretacci, \& Phillips 2010). Though officers' attitudes toward the citizenry were asked in some survey questions in the aforementioned research surveys as one part of the proxies representing police cynicism or support for community building, none of 
them focused on Chinese police attitudes toward the citizenry, nor was there any systematic review of relevant literature. Thus, very little is known about the attitudinal propensities on the citizenry among contemporary Chinese police officers, let alone factors influencing this vital aspect of police occupational attitudes. This study filled these knowledge gaps in the literature.

Two additional reasons justified this study. First, among the studies that have assessed police attitudes toward citizens, single attitudinal indicator such as "trust in citizens" and "willingness to offer comfort to citizens" were used most of the time (Brooks et al., 1993; Chen, 2016; DeJong, 2004; Haarr, 2001; He et al., 2005; Ingram \& Terrill, 2014; Paoline et al., 2000; Phillips, 2015; Sun, 2002; Sun et al., 2010; Worden, 1993). These studies thus failed to capture the comprehensiveness of officers' perceptions on the citizenry and various dimensions within the broad attitude. This study addressed this concern by analyzing officers' attitudes toward citizens along several important dimensions, including police trust in citizens, citizen cooperation with the police, citizen appreciation of police work, citizen input in police work, and citizen virtue.

Second, another void in previous research was the absence of study on the relationship between officers' role orientations (e.g., law enforcement and service) and their attitudes toward citizens. Police role orientations are indicators of officers' inclinations for different dimensions of police work. Officers who favor the service role may display different attitudes toward local residents, compared to those who endorse the traditional law enforcement and crime fighting role orientations (Brown, 1988; Chen, 2016; Gingerich \& Chu, 2006; Paoline, Myers, \& Worden, 2000; Skogan \& Hartnett, 1997; Sun et al., 2009, 2010; Wycoff \& Skogan, 1994). This study 
examined the relationship between offices' role orientations and their attitudes toward citizens.

Chinese police have faced some substantial challenges since the country started its economic reform in the late 1970s. The drastically increase in social stratification and rich-poor polarization in modern China dissolved the previous solitary coalitions between citizens and police in Mao's time. A massive influx of peasants into the cities as migrant workers, who became primary targets of law enforcement, contributed to an explosion of crime (Cao, 2007; Dutton \&Tianfu, 1993; Qi \& Oberwittler, 2009; Wang \& Wong, 2012; Wong, 2002; Xu, 2009). The polarization of the have and the have-not and social problems accompanying it generated increased resentment against police and petition campaigns among the citizens, causing successive violent confrontations and anger-venting mass incidents (Fewsmith, 2008; Liu, 1990; Rowen, 2007). On the aspect of the police work, there is a series of problems such as endemic corruption, heavy workload, and increased job risk (Tanner, 2004). All these drastic changes contributed to the complexity of policecitizens relations in China and influenced police perceptions of the public. Findings from this study would shed light on patterns of police outlooks toward citizens and provide directions for related policy making on improving police-community relations.

Using survey data collected from approximately 200 police supervisors in a Chinese metropolitan, this study analyzed the effects of officers' demographics, socialization experience, and role orientations on their attitudes toward citizens, including trust in citizens, citizen cooperation with the police, citizen appreciation of 
police work, citizen input in police work, and citizen virtue. Two research questions guided this study:

(1) Do officers' demographics, socialization experience, and role orientations affect their attitudes toward citizens?

(2) Are different dimensions of officers' attitudes toward citizens influenced by a distinctive same set of variables? 


\section{Chapter 2}

\section{LITERATURE}

\section{Recent Developments in Chinese Policing}

Policing and police-citizen relations in China have evolved over the past several decades. In this study, a two-stage division was adopted to illustrate such developments since the economic reforms started in the late 1970s: (1) 1978-1995: the pre-police-professionalization era; and (2) 1995 - present: the post-police-

professionalization era. It should be noted this division does not imply that the policecitizen relationship did not change within the same era, nor does it mean that the police-citizen relationship from the two eras share nothing in common.

Some features of the Chinese police structure and mass-line ideology were introduced first as background information as they tended to influence policing and police-citizen relations. The police system in China is not a centralized system, though it has many features of a centralized model (Fu, 2005; Jiao, 2001; Ma, 1997). From the organizational aspect, the police are under the dual leadership of the national Ministry of Public Security (MPS) and local governments. Specifically, MPS is responsible for supervising local police departments and ensuring that minimum standards in recruitment and training are met, while local governments take the primary responsibility for the administration and management of local police departments. This dual leadership is believed to have the advantages of ensuring a national professional standard and providing the local governments with some autonomy in determining their own priorities in policing (Dai, 2008). 
In spite of the unified and hierarchical policing structure and policies from the MPS to local police departments, the power of managing and leading police forces largely falls into the hands of local governments, fostering a decentralized feature of Chinese policing. There is significant control from local governments over many important issues such as the size, recruitment, chief nomination and budget of the local police agencies (Fu, 1994, 2001, 2005), giving the authority of steering the police forces into their local financial needs. Local police impose various punishments on individuals or organizations based on administrative rules and regulations established by local governments $(\mathrm{Fu}, 2005)$. It was reported in the 1990s that some local governments even demanded local police to fill some budgetary gap, and local police responded by extensively imposing fines on gambling, prostitution, and traffic offenses without using education or detention punishments (Dutton, 1992; Fu, 2005).

Mass-line is another feature of Chinese policing, as evidenced by the great number of police stations at the neighborhood level across the country. The mass line policing has both ideological importance and practical utility. As a comparatively homogenous and communitarianism nation, China is heavily influenced by the collectivism and Confucianism which emphasize on placing priority on the social functions of the family and group over an individual's straightly emotion expression, and on indoctrinating people with moral rules and education rather than obligation or fear (Dutton, 1992; Jiang et al., 2014;Troyer, 1989). Under this Chinese cultural tradition, police are responsible for educating citizens of moral codes and keeping informal social control by solving community problems and facilitating mediations (Jiao, 2001). 
The practicality of mass-line lies in social control over the huge population in China. There is a small number of officers (or police-citizen ratio) considering the huge population. In 2007, for example, there were 120 officers per 100, 000 inhabitants in China, compared to 348 officers per 100, 000 people in the U.S. Thus, Chinese police realized that good cooperation with the public was crucial to successful crime control and prevention. Field stations (the so-called pai-chu-suo) were set up throughout neighborhoods in urban China and towns or villages in rural China. Police rely upon and coordinate with the resident committees to promote social control and crime prevention activities. Thus, unlike their Western counterparts, Chinese officers' order maintenance role overlapped with their service role orientation through the informal social control such as educating residents and facilitating mediations under the mass line.

1978-1995

The open-door policy and market reform unprecedentedly accelerated China's social and economic developments. Deng Xiaoping's slogan "getting rich is glorious" liberated China from its suppression of the normal individual desire for material possession, contributing partly to the emergence of an anomie state and the rise of crime rate (Bakken, 2005; Cao, 2007). Powerful officials colluded with businessman, and citizens without power and means were forced to engage in criminal offenses (Cao \& Dai, 2001; Nee, 1996). During this era of policing, police's top priority was to "secure a stable social and political environment for economic reform to develop and prosper" (Wong, 2002, p. 290). National and local strike-hard campaigns were launched to suppress crime. During several waves of nationwide campaigns between 1983 and 1993, thousands of criminal suspects were massively arrested, swiftly 
sentenced, and harshly punished by the collective efforts of Chinese criminal justice agencies (Sun \& Wu, 2010).

Compared to their Western counterparts, Chinese police were empowered with broader authority and discretion in this era. Chinese police had administrative sanction power that allowed them to punish minor offenses, seize or seizure without any judicial approval (Ma, 1997). There were virtually no regulations for disciplinary procedures or citizen complaint mechanisms, and there was a lack of clarified supervision from prosecutors or judges (Ma, 1997). Although the broad discretion of police facilitated greater flexibility in offering service to and solving problem for citizens, it fertilized abuse of power.

There were some challenges posed to policing and the police-citizen relationship during this era of policing. First, the social class structure supporting the mass line ideology dissolved. Market economy reform incented people to use various ways to get material gain, and deeper social stratifications replaced the proletariatbourgeoisie class structure, which destroyed the basic foundation of the police-citizens mass line. Crime investigation was only police work but no more the whole proletarian class fight.

Second, police's image of devotion and dedication on serving people was undermined due to abusive behavior, unbalanced law enforcement and corruption. Pragmatic ideology and dominant importance of case number in officers' annual appraisal system fostered the neglect of due process and suspect's rights among officers. Police tended to defend the interests and privileges of the "haves", perfunctorily dealt with those of the "have-nots", and protected local business owners under the local government influence (Wong, 2002, 2009). As a result, police received 
meager support from the bottom social groups. What was even worse, some officers enforced the law in favor of the rich group under the drive of illegitimate payback (Wong, 2002). Although information on Chinese police corruption were kept confidential, some studies on corruption in China suggested that the years following the1978 reform witnessed a quantitative increase in corruption, and during the 1990s corruption underwent a qualitative change as high-level, high-stakes corruption increased under the prevalence of materialism (Wederman, 2004).

Finally, the collectivism tradition required the police to undertake not only crime fighting but also crime prevention and early intervention tasks. Officers were often blamed for the dramatic increase of crime after 1978. Some officers had to manipulate crime statistics by intentionally ignoring or not recording some offenses to lower crime rates in their jurisdictions. According to China's National Crime Study (NCS), local police failed to report about $70 \%$ to $80 \%$ of the crimes known to them in the years of 1985, 1987, and 1988 (Yu \& Zhang, 1999).

\section{5-current}

On a more positive note, the economic reform was also accompanied by a substantial legal reform in China. One step in the "rule of law" reform was the professionalization of the police force, marked by the passage of Police Law in 1995. It consisted of 56 articles that covered specific issues such as police organizations, duties, recruitment, training, power, disciplinary procedures, and citizen complaint mechanisms (Ma, 1997). Criminal Procedural Law, promulgated in 1996, also established restrictions on police powers and protections on suspects' rights (Ma, 2003). 
In this era of policing, the field station work in community was kept as an important policy and strategy. In 2002, the MPS officially launched community policing. It was estimated that more than 80,000 officers were reassigned to police neighborhood stations, whose manpower rose to about $83 \%$ of the total police force (Yin \& Zhang, 2007; Zhong, 2009).

The legal reform brought some restrictions on police power, which was elucidated by the protection of suspect's right in various laws, supervision on police from prosecutors, and emerging of various accesses for citizens to make complaints against police. For example, the 1996 Criminal Procedural Law allowed the defense attorney, as well as relatives of the suspects, to apply for the stop of any compulsory measures such as detention or arrest if the time span of the measure prescribed by law was exceeded (Ma, 1997). Additionally, the increased media attention, including reports or recordings of police misconduct on social media, has surfaced as an external supervision on the police. Cases of police corruption and misconduct in which police raped and abused prostitutes (Jeffreys, 2010) and took millions of dollars bribes (Areddy, 2009) were widely publicized.

Indeed, police-citizen relations attenuated because of increased critical attitudes toward police, the enlarged social distance between police and citizens, and citizen-police violent confrontations in protests and petitions. First, as Chinese citizens were exposed to democratic thoughts and reports of police abuse of power in the era of internet, they became more critical of the police authorities. Police were blamed for only protecting those with money and power, and people openly questioned the fairness and legitimacy of the police, generating hatred toward the police (Chen, 2016; Fu, 2009; Li, 2009; Meng, 2009; Zu, 2010). Support, respect and trust that Chinese 
frontline police felt from the public were far from sufficient, leading to a negative and cynical view on the public among officers (Bennett \& Schmitt, 2002, Chen, 2016).

Second, police-citizen confrontations during protests and demonstrations generated tensions between citizens and police. The transition into professionalization at the upper policy level was not fully transmitted into street level practice. There were widespread incidents of police's disrespecting the laws and brutally investigating crime, triggering repeated mass protests and violent demonstration events (Hu \& Dai, 2014; Li \& Ma, 2010; Ma, 2003; Shaw, 2010). In 2010, there were 180,000 protests, riots and other mass incidents happened in China, more than four times the total from a decade earlier (Orlik, 2011). Although illegal land seizure by local officials was often the leading cause of public anger and social unrest, protests and litigations against the police resulted directly from police misconduct and corruption were common (O’Brien \& Li, 2006).

Third, the expectation of police role in professionalization and complexity of police work created a dilemma for police. Citizens expected police to response, help, and rescue for all requests, whereas police complained about the work overload caused by the ambiguity of social service work. Studies suggested that Chinese police officers perceived a comparative high level of job strain from workload, inadequate support for the police force and social service role (Jiang, Xu, \& Deng, 2005; Sun, 2007). Another survey on frontline officers reported that 90 percent of the respondents experienced distressful psychological problems such as insomnia, nervousness, and depression (Wang, 2010). The latest study on Chinese police cynicism found that Chinese police held relatively negative attitudes toward citizens (Chen, 2016). 


\section{Police Officers' Attitudes Toward Citizens}

\section{Theoretical frameworks}

Two theories are relevant in explaining the possible attitudinal differences among Chinese police officers. The "predisposition theory" suggested that an officer's occupational attitudes were a reflection of his/her personal characteristics and background (e.g. age, race, gender, educational attainment, marital status and parental educational attainment and socio-economic status). Officers perceived the police role, work and citizens differently because they came to the job with different demographic characteristics (Roberg, Crank, \& Kuykendall, 2000; Sun \& Payne, 2004).

Empirical studies showed mixed results for this theory. Some studies on typologies of police officers showed that officers were not homogenous in their occupational attitudes and operational styles. For example, compared to male officers, female officers were less aggressive in using force (Brooks et al., 1993), tended to have a broader role orientation (Sun, 2003), and had higher global attitudes toward community policing (Schafer, 2002). Some studies found that college educated officers were more positive toward legal restrictions (Worden, 1990) and peer groups and top managers (Sun, 2002), but less supportive of community policing activities (Winfree, Bartku, \& Seibel, 1996) than their less educated counterparts. However, other studies either showed a weak connection between officers' background characteristics and occupational attitudes (Sun, 2002), or demographic factors' effects was mediated by work environment factors (Schuck, 2014). It is thus fair to argue that the predisposition theory has yet to receive consistent support from past research.

A second theoretical perspective was the "differential socialization/experience theory", which posited that officers' attitudes were influenced by different socialization and experiences in their work environment (Roberg et al., 2000). 
Officers' training experience (e.g. the amount and type of training received), work units (e.g. district offices versus field stations), assignments (e.g. community policing officers versus regular officers), and experiences with citizens were related to their occupational attitudes (Barlow \& Barlow, 2000). For example, community policing training and assignment improved officers' overall satisfaction with their job (McElroy, Cosgrove, \& Sadd, 1993; Skogan \& Hartnett, 1997). However, other studies showed none or only a weak association between community policing training and work-related attitudes (Paoline et al., 2000; Sun \& Chu, 2008a, 2008b). Like the predisposition theory, the differential experience theory has so far received only modest support from empirical research.

Empirical test on officers' attitudes toward citizens

Previous studies on Chinese and U.S. officers' attitudes toward citizens were reviewed, given that a rather small number of studies have been conducted on Chinese police attitudes toward citizens and most of them were under the survey questionnaires derived from Western theoretical frameworks. It should be noted that comparative studies have found more similarities than differences in officers' crime ideologies regarding crime control and prevention between China and the U.S. (Cao \& Cullen, 2001; Jiao, 1998, 2001).

Based on the predisposition theory and differential socialization theory, two groups of factors were reviewed: demographic determinants and socialization/experience determinants.

\section{Demographic characteristics}

A few studies touched on the impact of gender on officers' attitudes toward citizens. One study found that gender was indirectly significantly related to officer's 
view on citizens, with female officers in one police department (but not in the second police department) less likely than male officers to assume responsibility for ordermaintenance service for communities and citizens (Paoline et al., 2000). In a series of comparative research on Taiwan police and the U.S. police, Sun and Chu reported that Taiwan female officers displayed more critical views of citizens than their male counterparts (Chu \& Sun, 2007; Sun \& Chu, 2006, 2008a, 2008b). Another study indicated that although officers' sex was not related to distrust of citizens, the interaction between sex, race and education affected officer attitudes toward citizens: nonwhite male officers were more likely than nonwhite female to distrust citizens, and nonwhite female officers were less likely than white female officers to provide comfort to citizens (DeJong, 2004). Studies also reported that female officers were less likely than male officers to assimilate hyper-masculine beliefs into their identity, leading to less negative attitudes toward citizens (Schuck, 2014). Other studies, however, showed either a weak linkage between gender and officer perceptions of citizens (Brooks et al., 1993; Chu \& Sun, 2007; Paoline et al., 2000; Sun, 2002; Poteyeva \& Sun, 2009; Worden, 1993) or no relationship between them (Chen, 2016; Sun et al., 2010).

Gender effect, though mixed, reflected the distinct feeling of female officers in the policing occupation, a venue featured with paramilitary and masculinist (Martin, 1980; Martin \& Jurik, 2006; Owings, 1925; Schulz, 1995). Female officers are under the extra burden in this occupation as their male peers doubt that police women would soften police image, assume that they pass police academy training under a lighter standard, and feel hard to respect a woman in a position of power. Women have less voice in decision making and less opportunities in promotion and they tend to 
undertake less important, non-front-line assignments most of the time (Martin, 1980). China, a traditional patriarchy cultural country, is not immune from the gendered effect in the police occupation. Female officers are usually assigned to do administrative work, whereas male officers are put in the front line dealing with citizen disputes and problems.

Age was the second demographic characteristic that was used to examine officers' attitudes toward citizens. However, compared with years of work experience (see below for more discussion of year of police experience), age received much less attention. Only a handful of studies included age in the analysis of officers' attitudes toward the citizenry, either reporting no relationship (Sun et al., 2010) or a weak association (Brooks et al., 1993; Haarr, 2001; Sun et al., 2009; Worden, 1993). Given such a limited of studies, more research is warranted before conclusive statements could be made about the effect of officers' age.

Officers' educational attainment was taken into consideration in previous studies. Similar to the impact of gender, officer educational background was found to have an inconsistent effect on police attitudes toward citizens. Some studies found that college-educated officers held more negative views of citizens (Brooks et al., 1993; Paoline at al., 2000), and better educated policewomen were more inclined to support the notion of distrusting citizens (Sun \& Chu, 2006). However, there were also studies reporting that education could not explain much variation in police officers' views on citizens (Chen, 2016; Moon \& Zager, 2007; Sun, 2002; Sun \& Chu, 2006; Sun et al., 2010). One study found interaction effects among gender, race, and education, with female officers with college degree more likely to be distrustful of citizens (DeJong, 2004). 
Studies on American officers' attitudinal outlooks showed that minority officers were more supportive of building community ties (Lurigio \& Skogan, 1994; Skogan \& Hartnett, 1997). Others found interaction effects among race, gender and education with nonwhite, male officers with college degrees were significantly more likely to be distrustful of citizen (DeJong, 2004). However, there were also reports indicating race could not explain much of the variation in officers' views on citizens (Paoline et al., 2000; Sun, 2002). There has been no study testing the effect of race or ethnicity on police's attitudes toward the citizenry in China due mainly to a small proportion of minority population (9\%). A recent study found that Han majority ethnicity was related to Chinese police supervisors' role orientations, with Han officers showing more favorable attitudes toward the crime fighting but less supportive for the order maintenance role than their non-Han counterparts (Sun et al., 2016). Such attitudinal differences may influence Chinese police officers' perceptions of local residents.

\section{Socialization/experiences characteristics}

Work seniority was closely related to officers' socialization experience. The effect of year of police experience was investigated in past studies on officers' attitudes toward citizens. Most studies showed a positive relationship between them: experienced officers held more positive attitudes toward citizen (Moon \& Zager, 2007; Paoline et al., 2000; Sun, 2002; Sun \& Chu, 2006). A curvilinear relationship between seniority and trust in citizen was found in one study on Chinese police cynicism. That was, both officers with experiences more than 11 years and less than 5 years were less distrustful of citizens than those with 6-10 years of experience (Chen, 2016), supporting the classical discovery of Niederhoffer that police cynicism reached its 
peak between 7 to 10 years of service before declining (Cooper, 1982; Niederhoffer, 1967). However, a study on police constables in Norway reported a negative linear relationship between tenure and distrust of citizens (Burke \& Mikkelsen, 2005). Still, other studies found no relationship between work seniority and police attitudes toward citizens (Brooks et al., 1993; Worden, 1993).

A few past studies analyzed the connection between officers' work assignments (e.g., community policing) and their attitudes toward local residents. Mixed results were reported. Some studies reported a positive relationship between community policing assignment and trust in citizens (Paoline et al., 2000). Others found a negative relationship between community policing assignments and officers' attitudes toward citizen cooperation (Sun, 2002). Still, others suggested no relationship between the two factors (Chen, 2016). This current study examined whether Chinese field station police officers showed different attitudes toward citizens from none-field-station officers, because field station officers engaged in more interactions with local residents and plausibly expressed more favorable attitudes toward them.

\section{Role orientations}

Beside officer demographic characteristics and socialization characteristics, it is argued that officers' role orientations could influence their attitudes toward citizens. As studies on police culture suggested, officers who endorsed a traditional role of crime fighting would likely to display the "them-versus-us" mentality and subsequently to distrust citizens (Buerger, 2007; Caplan, 2003; Niederhoffer, 1967; Pollock, 2012; Reiner, 2010; Rubinstein, 1973; Skolnick \& Bayley, 1988a, 1988b; Wooden \& Rogers, 2014), while officers who believed in helping citizens to solve 
their problems and protect their business tended to view citizens as grateful and supportive to the police (Karp, 2000; Moore, Trojanowicz \& Kelling, 1988; Paoline, 2003; Rosenbaum, 1988).

In this research, two role orientation variables were examined regarding their effect on officers' attitude on citizens: crime fighting role orientation and serving citizens orientation. As mentioned above, under the mass line ideology Chinese officers' service task covers the practices of both order maintenance and service orientations commonly distinguished in Western countries. It was plausible that police favoring the crime fighting role were more prone to have negative attitudes toward citizens, while officers supporting serving citizens were more likely to have positive views of citizens. 


\section{Chapter 3}

\section{METHODOLOGY}

\section{Data collection and sample}

Data used in the study were collected from a police college located in a southwestern city in China. The college was founded in the 1950 s to provide basic pre-service training to police officers. Over the past several decades, the college has steadily expanded into a higher education institution that currently offers bachelor's degree programs through its eight departments/majors to high school graduates and inservice, short-term training courses or programs to police officers. A survey instrument, which contained 61 items, was developed based on past research on police occupational attitudes in both the U.S. and China (Chu \& Sun, 2007; Paoline et al., 2000; Sun et al., 2009; Sun \& Chu, 2006, 2008a, 2008b). The questionnaire was designed with the purpose to obtain information on officers' attitudes toward work priorities, community policing, citizens, and job satisfaction as well as their background characteristics.

The survey was carried out with the assistance of an instructor, who collected survey data during the winter of 2014 from a few hundred police supervisors who were attending an on-the-job training course at the college. These police supervisors were assigned to various units within the city police force and held a rank of sergeant or above. They were informed in the beginning of their training course by the instructor about the opportunity of participating in this research project. The officers were aware of the purpose of the study and the voluntary and confidential nature of 
their participation before taking the survey. A total of 230 surveys were distributed to officers in their classrooms and 219 surveys were returned, resulting in a $95 \%$ response rate. Nine surveys had to be dropped because of missing responses to items used in the analysis. In the end, a final sample of 210 police supervisors was used.

As shown in Table 1, the majority of sample officers were male (76\%) and the Han majority (92\%). The mean of age and year of police experience was 35 years of old and 11 years, respectively. About a quarter (24\%) of respondents were working in field stations. Because of the lack of official demographic data on officers and supervisors of the whole police department in the city, the representation of sample officers could not be assured. However, the researcher's own knowledge about the police force indicated that there was a reasonable congruence between the study sample and the population.

\section{Measures}

The dependent variables in this study were five dimensions reflecting police attitudes toward citizens (see Table 1). Citizen cooperation with police was an additive scale that included three items: (1) most citizens will report to police when they see something or somebody suspicious, (2) most citizens will offer information when police ask them to help in finding suspects, and (3) citizens are willing to report to police when they witness a crime. The original response categories ranged from strongly agree (1) to strongly disagree (6) and were reverse coded so that a higher score reflected a stronger agreement with the notion of citizen willingness to cooperate with the police. The scale had a Cronbach's alpha of .62, suggesting acceptable reliability. 
Table 1 Descriptive Statistics for Variables in Regression Analysis $(n=210)$

\begin{tabular}{lrrcc}
\hline Variables & M & SD & Range & $\alpha$ \\
\hline Dependent variables & & & & \\
Citizen cooperation with police & 11.75 & 2.82 & $4-18$ & .62 \\
Citizen virtue & 9.12 & 1.79 & $2-12$ & .71 \\
Citizen appreciation of police work & 1.58 & .91 & $1-6$ & -- \\
Trust in citizens & 3.33 & 1.32 & $1-6$ & -- \\
Citizen input in police work & 3.34 & .76 & $1-4$ & \\
Independent variables & & & & \\
Male & .76 & .43 & $0-1$ & -- \\
Age & 34.47 & 2.21 & $28-42$ & -- \\
Racial majority/Han & .92 & .28 & $0-1$ & -- \\
Educational attainment & 2.98 & .81 & $1-5$ & -- \\
Year of police experience & 11.52 & 2.87 & $1-24$ & -- \\
Field station & .24 & .43 & $0-1$ & - \\
Crime fighting orientation & 11.00 & 1.39 & $6-12$ & .75 \\
Service orientation & 5.42 & 1.82 & $2-8$ & .71 \\
\hline
\end{tabular}

Note: $\mathrm{M}=$ mean; $\mathrm{SD}=$ standard deviation; $\alpha=$ Cronbach's alpha

Citizen virtue was also an additive scale comprised of two items asking respondents whether they agreed that: (1) most citizens will do right things, and (2) citizens have goodwill. The original response categories for both items varied from strongly agree (1) to strongly disagree (6) and were reverse coded. A higher score of the index suggested a stronger belief of citizen having good virtue. The scale had a Cronbach's alpha of .71, indicating acceptable reliability.

Citizen appreciation of police work was constructed based on a single item asking officers' agreement with the statement "Most citizens don't understand how hard police work is". Response categories ranged from strongly agree (1) to strongly disagree (6). A higher score implied a higher magnitude in believing citizen appreciation of police work. 
Trust in citizens was also measured through a single item: "Police have good reason to distrust citizens". Response categories varied from strongly agree (1) to strongly disagree (6). A higher score indicated a higher degree of trust in citizens.

Citizen input in police work was a single item variable, based on the responses to the statement "Police should work together with citizens to solve their problems in the jurisdiction". The original response categories ranged from strongly agree (1) to strongly disagree (4) and were reverse coded so that a greater value suggested a higher degree of agreement with the statement.

The independent variables included three groups of variables representing officers' demographic characteristics, socialization/experience characteristics, and role orientations. Officers' demographic characteristics included gender, age, ethnic Han and educational attainment. Male was coded as dummy variables with 1 representing male. Age was measured in years. A dummy variable indicated whether the officer was the racial majority Han (1) or not (0). Educational attainment was a five-category variable (1=high school; $5=$ master's degree or above). Socialization/experience characteristics included field station, a dummy variable indicating whether the supervisor worked at a field station (1) or not (0), and year of police experience, a continuous variable measured in years.

Role orientations included crime fighting orientation and service orientation. Crime fighting orientation was an additive variable asking officers to rate the importance of some police goals: (1) the goal of policing is attacking crime, (2) the goal of policing is anti-terrorists, and (3) the goal of policing is attacking narcotic crime. Response categories ranged from very unimportant (1) to very important (4). A higher score on the scale suggested a stronger orientation toward the crime fighting 
role. The Cronbach's alpha associated with the scale is .75 , indicating acceptable internal consistency.

Service orientation was an additive scale of two items: (1) Helping citizens to solve their difficulties is as important as law enforcement, and (2) police should solve non-crime problems for community. Response categories ranged from strongly disagree (1) to strongly agree (4). The scale had a Cronbach's alpha of .71, suggesting acceptable reliability. As discussed earlier, the service role of Chinese police encompasses both order maintenance and service, which is represented by the two items used to construct the variable. 


\section{Chapter 4}

\section{RESULT}

Five separate regression models (see Table 2) were estimated to answer the two research questions of this study. Model 1 presented the effects of the independent variables on officers' attitudes toward citizen cooperation with police. Among officer demographics, only gender was a significant predictor. Male officers were significantly less likely than female officers to support the notion of citizen cooperation with police. None of the experiential and orientation variables were significantly related to attitudes toward citizen cooperation. The model was not very successful, explaining only $6 \%$ of the variation in officer attitudes toward citizen cooperation with the police.

In model 2, the relationships between independent variables and officers' perceptions of citizen virtue were presented. Similar to the results in model1, only one officer background characteristic exerted a significant effect, with older officers more likely to agree with the statements of citizen virtue. The two socialization variables were unrelated to attitudes toward citizen virtue. Both role orientations were positively linked to citizen virtue. Officers with stronger role orientations of crime fighting and service appeared to be more likely to believe citizens had good virtue. All independent variables together accounted for $9 \%$ of the variation in police attitudes toward citizen virtue. 
Table 2 Multiple Regression Summary

\begin{tabular}{|c|c|c|c|c|c|}
\hline Variable & $\begin{array}{c}\text { Citizen } \\
\text { cooperation with } \\
\text { police }^{\mathrm{a}}\end{array}$ & $\begin{array}{l}\text { Citizen } \\
\text { virtue }^{\mathrm{a}}\end{array}$ & $\begin{array}{c}\text { Citizen } \\
\text { appreciation } \\
\text { of police work }\end{array}$ & $\begin{array}{l}\text { Trust in } \\
\text { citizens }^{b}\end{array}$ & $\begin{array}{l}\text { Citizen input } \\
\text { in police } \\
\text { work }^{\mathrm{b}}\end{array}$ \\
\hline \multicolumn{6}{|l|}{$\begin{array}{l}\text { Background } \\
\text { characteristics }\end{array}$} \\
\hline Male & $\begin{array}{l}-1.56^{*} \\
(.047)\end{array}$ & $\begin{array}{c}.04 \\
(.30)\end{array}$ & $\begin{array}{l}-.29 \\
(.35)\end{array}$ & $\begin{array}{l}-.34 \\
(.30)\end{array}$ & $\begin{array}{c}.47 \\
(.38)\end{array}$ \\
\hline Age & $\begin{array}{l}-.40 \\
(.10)\end{array}$ & $\begin{array}{l}.14 * \\
(.06)\end{array}$ & $\begin{array}{l}-.11 \\
(.07)\end{array}$ & $\begin{array}{l}-.03 \\
(.06)\end{array}$ & $\begin{array}{c}.09 \\
(.08)\end{array}$ \\
\hline Ethnic majority/Han & $\begin{array}{l}-.10 \\
(.76)\end{array}$ & $\begin{array}{l}-.33 \\
(.49)\end{array}$ & $\begin{array}{l}.32 \\
(.53)\end{array}$ & $\begin{array}{l}-.13 \\
(.48)\end{array}$ & $\begin{array}{l}.32 \\
(.60)\end{array}$ \\
\hline Educational attainment & $\begin{array}{c}.01 \\
(.25)\end{array}$ & $\begin{array}{l}.17 \\
(.16)\end{array}$ & $\begin{array}{l}-.05 \\
(.19)\end{array}$ & $\begin{array}{l}-.07 \\
(.16)\end{array}$ & $\begin{array}{l}.57 * * \\
(.20)\end{array}$ \\
\hline \multicolumn{6}{|l|}{ Socialization/experience } \\
\hline $\begin{array}{l}\text { Year of police } \\
\text { experience } \\
\text { Field station }\end{array}$ & $\begin{array}{l}-.03 \\
(.07) \\
-.02 \\
(.47)\end{array}$ & $\begin{array}{c}.01 \\
(.05) \\
-.31 \\
(.30)\end{array}$ & $\begin{array}{l}.01 \\
(.06) \\
-.42 \\
(.33)\end{array}$ & $\begin{array}{l}-.03 \\
(.05) \\
.02 \\
(.30)\end{array}$ & $\begin{array}{l}.08 \\
(.06) \\
-.43 \\
(.37)\end{array}$ \\
\hline \multicolumn{6}{|l|}{ Role orientations } \\
\hline $\begin{array}{l}\text { Crime fighting } \\
\text { orientation } \\
\text { Service orientation }\end{array}$ & $\begin{array}{l}.05 \\
(.14) \\
.13 \\
(.11)\end{array}$ & $\begin{array}{l}.25^{*} \\
(.10) \\
.16^{* *} \\
(.07)\end{array}$ & $\begin{array}{c}-.27 * * \\
(.10) \\
.10 \\
(.08)\end{array}$ & $\begin{array}{l}-.07 \\
(.09) \\
.10 \\
(.07)\end{array}$ & $\begin{array}{l}.28 * * \\
(.11) \\
.75^{* * *} \\
(.10)\end{array}$ \\
\hline $\mathrm{R}^{2} /{ }^{\mathrm{d}}$ Nagelkerke $\mathrm{R}^{2}$ & .06 & .09 & .07 & .02 & .41 \\
\hline
\end{tabular}

${ }^{a}$ Entries are standardized regression coefficients from OLS regression, with standard errors in parentheses.

${ }^{\mathrm{b}}$ Entries are ordinal regression estimates, with standard errors in parentheses.

$* p<.05, * * p<.01, * * * p<.001$ 
Model 3 presented the results for the model of citizen' appreciation of police work. Neither background nor socialization characteristics were predictive of such officers' attitude. The only significant predictor is the crime fighting orientation. The stronger the officers hold the crime fighting orientation, the less likely they would perceive citizen appreciation of police work.

Model 4 was least successfully as none of the independent variables were significantly related to police officers' attitude toward trust in citizens. Finally, in model 5, officers' opinion on citizens' input in police work was significantly associated with their educational attainment. The higher the education level of an officer had, the higher probability would be for him or her to attach importance to citizen involvement in police work. Both role orientation variables were significantly positively related to perceptions of citizen input in police work. Those hold stronger orientation in crime fighting and service were more likely to agree that citizens should have input in police work. 


\title{
Chapter 5
}

\section{DISCUSSION}

\begin{abstract}
Although studies have investigated various attitudinal outlooks of police officers, there were few attempts to understand what factors affect officers' attitudes toward citizens. Even rarer was research assessed police occupational attitudes in transitional China, where police-community relations have faced great challenges in recent decades. This study represented one of the first attempts to investigate the connections between Chinese police demographics, socialization/experience and role orientation factors and their attitudes toward citizens. Three major findings emerged from the analysis.
\end{abstract}

First, neither the predisposition theory, nor the differential socialization/experience theory is effective in predicting five aspects of officer attitudes toward citizens. Although gender, age and educational attainment were linked to officer perceptions of the citizenry in three separate models, their impacts were not consistent and each was limited to a single model. Nonetheless, a few interesting findings are worthy of discussion. For example, I found that male officers were more critical than their female counterparts in their opinions on citizen cooperation with the police. This finding reflected the gendered work assignments and their effect on officers' attitudes toward citizen cooperation. Female officers are more likely to undertake administrative and supportive tasks in line with their traditional gender-role expectations, whereas male officers usually undertake front line work assignments. Thus, male officers have more opportunities to encounter 
unsupportive citizens in dealing with neighborhood disorder and crime problems, which may lower their evaluations of citizen cooperation with the police.

I also found that older and better educated supervisors were more inclined to favor the notion of citizen virtue and input, respectively. One may speculate that older officers have more life experiences and developed a more realistic view of the nature of human beings, leading to more favorable attitudes toward citizen virtue. One may also suspect that better educated Chinese police supervisors might have more opportunities to learn modern democratic and policing theories, which could foster respects on human rights and appreciation of citizens' role in community policing, fostering greater support for citizen input in police work. Our data do not have direct evidence to support or refute any of these possible explanations, however. Future studies should be conducted to further test the relationships between these officer background characteristics and their occupational attitudes.

Although previous research has confirmed the importance of socialization in shaping officer occupational outlooks (e.g., Van Maanen, 1974), the "differential socialization/experience" perspective received no support in this study. Both year of police experience and field station assignment were weakly connected to officers' attitudes toward citizens. Such a weak linkage could be the limitation associated with our measurement as working in field station as a socialization variable was constructed as a dummy variable, failing to adequately reflect the complex process of socialization and the complexity of work environment that officers experienced.

Future studies should employ in-deep interviews or ethnographic work to untangle the connections between officer socialization experience and their job-related attitudes. 
Second, our findings suggest that officer occupational attitudes are not standalone but highly intertwined phenomena as officers' role orientations are significantly related to multiple dimensions on attitudes toward the citizenry. A role tendency toward both crime fighting and service is accompanied by more favorable perceptions of citizen virtue and input in police work. It seems that the seemingly contradictory orientations of crime fighting and service do not have a different impact on how officers view local residents. Chinese officers might be able to reconcile the differences between the two orientations and place them as equally important as the agency or even the public would like to expect. Interestingly, our results also show a negative link between the crime fighting orientation and citizen appreciation of police work. Perhaps getting public appreciation of police work becomes particularly difficult in transitional societies where many changes and behavior have to be brought into order directly by law enforcement. In other words, officers may feel much easier to make judgment on citizen virtuous intentions and input in police work, but they are less sanguine about the comparability of their strong law enforcement orientation and the belief of truly appreciative citizens. Given the relevance of role orientations in assessing other police attitudes, future research should continue to explore the interconnectedness of attitudinal dimensions displayed by officers.

Finally, factors in the models exerted different influences over various dimensions of officers' attitudes toward citizens. For example, the two role orientations affected only officers' perceptions of citizen virtue and input but were weakly connected to views of citizen cooperation with and trust in the police. In addition, as mentioned above, officer gender, age and education exerted a significant effect on three different attitudinal dimensions regarding local residents. Collectively, 
our findings indicate the need for future studies to measure officer attitudes toward citizens along different dimensions and perhaps the development of explanatory models that are suitable for distinguishable attitudes.

Although this study has made a genuine contribution to the existing literature, a few limitations should be noted. First, the results were based on a cross-sectional analysis, which were susceptible to problems of causal ordering. For example, although I found that officer role orientations influenced their attitudes toward citizen virtue, it is possible that officer views of citizen virtue shape their developments of role orientations. Such a potential reciprocal relationship should be further assessed in future research. Second, this study was based on data collected from police supervisors in a large metropolitan in China. Findings of this study thus may not be generalized to supervisors in smaller or rural police departments, where task requirements and work environments could be quite different. Third, this study only examined police supervisors' attitudes toward citizens. Some of the incongruence between our results and previous findings might be caused by the sample group exclusively consisted of higher ranked officers. Thus, our findings should be interpreted with the awareness of over-universalization to rank and file. More research is needed to explore officers in different ranks in order to assess the congruence (or incongruence) in their attitudes. Finally, although our analysis yielded some findings on officers' attitudes toward the citizenry, it also suggested the inadequacy of officers' demographics and socialization factors in accounting for their views of citizens. Except the model on citizen input in police work that explained more than $40 \%$ of the variance, all models only explained a small portion of variance in attitudes toward local residents. Future studies should consider incorporating other 
levels of predictors, such as organizational cultures and leadership styles, to advance the test on officer subjective outlooks related to the citizenry.

Findings of this study reveal several implications for the Chinese police. First, our findings clearly show a link between officer role orientations and attitudes toward citizens, particularly citizen virtue and input in police work. This implies that if police top brass would like to cultivate officers' views of virtuous citizens and a greater citizen role in police work, then programs and trainings aiming at strengthening their acceptance of both law enforcement and service roles should be put into place.

Second, certain groups of officers could be targeted to improve their perceptions of the citizenry. For instance, male officers' attitudes toward citizen cooperation may be improved by rotating them among different units and assignments. Similarly, inservice training and managerial support could be rendered to younger and less educated officers who are less optimistic about citizen virtue and input in police work. A general positive attitude toward local residents and a healthy police-community relationship would undoubtedly not only benefit the Chinese police but also facilitate domestic governance and social stability in China. 


\section{REFERENCES}

Areddy, J. (2009, January 01). Chinese trial offers peek into police corruption; government cracks down on organized crime, investigating bribery and extortion allegations against hundreds of officials. The Wall Street Journal Eastern Edition, pp. A13, 1.

Bakken, B. (2005). Introduction: Crime, control, and modernity in China. In B. Bakken (Ed.), Crime, punishment, and policing in China (pp. 1-28). Lanham, MD: Rowman \& Littlefield.

Barlow, D., \& Barlow, M. (2000). Police in a multicultural society: An American story. Waveland, IL: Prospect Heights.

Beehr, T., Johnson, L., \& Nieva, R. (1995). Occupational stress: Coping of police and their spouses. Journal of Organizational Behavior, 16, 3-25.

Bennett, R., \& Schmitt, E. (2002). The effect of work environment on levels of police cynicism: A comparative study. Police Quarterly, 5, 493-522.

Brandl, S., Frank, J., Worden, R., \& Bynum, T. (1994). Global and specific attitudes toward the police: Disentangling the relationship. Justice Quarterly, 11, 119134. 
Brandl, S., Frank, J., Wooldredge, J., \& Watkins, R. (1997). On the measurement of public support for the police: A research note. Policing: An International Journal of Police Strategies \& Management, 20, 473-480.

Brandl, S., Stroshine, M., \& Frank, J. (2001). Who are the complaint-prone officers? An examination of the relationship between police officers' attributes, arrest activity, assignment, and citizens' complaints about excessive force. Journal of Criminal Justice, 29, 521-529.

Brooks, L., Piquero, A., \& Cronin, J. (1993). Police officer attitudes concerning their communities and their roles: A comparison of two suburban police departments. American Journal of Police, 12, 115-139.

Brown, J., \& Langan, P. (2001). Policing and homicide, 1976-98: Justifiable homicide by police, police officers murdered by felons. Washington, DC: U.S. Department of Justice, Office of Justice Programs, Bureau of Justice Statistics. Brown, M. (1988). Working the street: Police discretion and the dilemmas of reform. New York, NY: Russell Sage Foundation.

Buerger, M. (2007). Cynicism, police. In J. Greene (Eds.), The encyclopedia of police science (pp. 370-379). New York, NY: Routledge.

Burke, R., \& Mikkelsen, A. (2005). Career stage and police cynicism. Psychological Reports, 96, 989-992.

Cao, L. (2007). Returning to normality: Anomie and crime in China. International Journal of Offender Therapy and Comparative Criminology, 51, 40-51. 
Cao, L., \& Cullen, F. (2001). Thinking about crime and control: A comparative study of Chinese and American ideology. International Criminal Justice Review, 11, 58-81.

Cao, L., \& Dai, Y. (2001). Inequality and crime in China. Contributions in Criminology and Penology, 53, 73-88.

Cao, L., \& Stack, S. (2005). Confidence in the police between America and Japan: Results from two waves of surveys. Policing: An International Journal of Police Strategies and Management, 28, 139-151.

Caplan, J. (2003). Police cynicism: Police survival tool? The Police Journal, 76, 304313.

Carter, D., \& Radelet, L. (2002). The police and the community. Upper Saddle River, NJ: Prentice hall.

Chen, Z. (2016). An exploratory study of police cynicism in China. Policing: An International Journal of Police Strategies \& Management, forthcoming. Chevigny, P. (1969). Police power: police abuses in New York City. New York, NY: Pantheon Books.

Chu, D., \& Sun, I. (2007). A comparison of Taiwanese and American police supervisors' attitudes. Police Quarterly, 10, 63-86.

Cooper, W. (1982). Police officers over career stages. Canadian Police College Journal, 6, 93-112.

Correia, M. (2000). Citizen involvement: How community factors affect progressive policing. Washington DC: Police Executive Research Forum. 
Cuvelier, S., Jia, D., \& Jin, C. (2015). Chinese police cadets' attitudes toward police roles revisited. Policing: An International Journal of Police Strategies \& Management, 38, 250-264.

Dai, M. (2008). Policing in the People's Republic of China: A review of recent literature. Crime, Law and Social Change, 50, 211-227.

DeJong, C. (2004). Gender differences in officer attitude and behavior: Providing comfort to citizens. Women and Criminal Justice, 15, 1-32.

Dutton, M. (1992). Policing and punishment in China: From patriarchy to "The People”. Cambridge, UK: Cambridge University Press.

Dutton, M., \& Tianfu, L. (1993). Missing the target? Policing strategies in the period of economic reform. Crime and Delinquency, 39, 316-336.

Engel, R., \& Worden, R. (2003). Police officers' attitudes, behavior, and supervisory influences: An analysis of problem solving. Criminology, 41, 131-166.

Fewsmith, J. (2008). An "anger-venting" mass incident catches the attention of China's leadership. China Leadership Monitor 26, 1-10.

Frank, J., Brandl, S., \& Watkins, R. (1997). The content of community policing: A comparison of the daily activities of community and "beat" officers. Policing: An International Journal of Police Strategies \& Management, 20, 716-728.

Fu, H. (1994). A case for abolishing shelter for examination: Judicial review and police powers in China. Police Studies, 17(4), 41-60.

Fu, H. (2001). After dictatorship: The nature and function of the police in post-Mao China. In M. Amir, \& S. Einstein (Eds.), Policing, security and democracy: 
Theory and practice (pp. 259-284). Chicago, IL: The Office of International Criminal Justice, The University of Illinois at Chicago.

Fu, H. (2005). Zhou Yongkang and the recent police reform in China. The Australian and New Zealand Journal of Criminology, 38, 241-253.

Fu, L. (2009). The root of "duo mao mao" incident lies in the institutional imperfection. Legal Science, 4, 58-65.

Gabbidon, S., \& Greene, H. (2012). Race and crime. Thousand Oaks, CA: Sage.

Gau, J., \& Brunson, R. (2015). Procedural injustice, lost legitimacy, and self-help: Young males' adaptations to perceived unfairness in urban policing tactics. Journal of Contemporary Criminal Justice, 31, 132-150.

Gingerich, T., \& Chu, D. (2006). A comparative perspective of community policing in Taiwan and Washington State. Asian Journal of Criminology, 1, 119-135.

Goldsmith, A. (2005). Police reform and the problem of trust. Theoretical criminology, 9, 443-470.

Haarr, R. (2001). The making of a community policing officer: The impact of basic training and occupational socialization on police recruits. Police Quarterly, 4, 402-433.

He, N., Zhao, J., \& Ren, L. (2005). Do race and gender matter in police stress? A preliminary assessment of the interactive effects. Journal of Criminal Justice, 33, 535-547. 
Holmes, S., Reynolds, K., Holmes, R., \& Faulkner, S. (1998). Individual and situational determinants of police force: An examination of threat presentation. American Journal of Criminal Justice, 23, 83-106.

Hu, M., \& Dai, M. (2014). Confidence in the criminal justice system: Differences between citizens and criminal justice officials in China. Criminology and Criminal Justice, 14, 503-524.

Ingram, J., Paoline, E., \& Terrill, W. (2013). A multilevel framework for understanding police culture: The role of the workgroup. Criminology, 51, 365-397.

Ingram, J., \& Terrill, W. (2014). Relational demography and officer occupational attitudes: The influence of workgroup context. Journal of Criminal Justice, 42, 309-320.

Jeffreys, E. (2010). Exposing police corruption and malfeasance: China's virgin prostitute cases. The China Journal, 63, 127-149.

Jiang, S., Lambert, E. G., Liu, J., \& Saito, T. (2014). Formal and informal control views in China, Japan, and the US. Journal of Criminal Justice, 42, 36-44.

Jiang, J., Xu, Y. \& Deng, Z. (2005). The relationship between job strain and job stress. Chinese Mental Health Journal, 3, 207-207.

Jiao, A. (1998). Community-oriented policing and policing-oriented community. Journal of Crime and Justice, 21, 135-158.

Jiao, A. (2001). Police and culture: A comparison between China and the United States. Police Quarterly, 4, 156-185. 
Karp, D. (2000). Community justice: An emerging field. Lanham, MD: Rowan \& Littlefield.

Lasley, J. (1994). The impact of the Rodney King incident on citizen attitudes toward police. Policing and Society: An International Journal, 3, 245-255.

Li, H. (2009). The value of Internet catchphrases in communication studies. Youth Journalist, 16, 91-93.

Li, Y. \& Ma, Y. (2010). Adjudication and legal reforms in contemporary China. Journal of Contemporary Criminal Justice, 26, 36-52.

Liska, A., \& Yu, J. (1992). Specifying and testing the threat hypothesis: Police use of deadly force. In A. Liska (Eds.), Social threat and social control (pp. 53-68). Albany, NY: State University of New York Press.

Liu, A. (1990). Aspects of Beijing's crisis management: The Tiananmen Square demonstration. Asian Survey, 30, 505-521.

Lurigio, A., \& Skogan, W. (1994). Winning the hearts and minds of police officers: An assessment of staff perceptions of community policing in Chicago. Crime \& Delinquency, 40, 315-330.

Ma, Y. (1997). The Police Law 1995: Organization, functions, powers and accountability of the Chinese police. Policing: An International Journal of Police Strategy and Management, 20, 113-135.

Ma, Y. (2003). The powers of the police and the rights of suspects under the amended Criminal Procedure Law of China. Policing, 26, 490-510. 
MacDonald, J., \& Stokes, R. (2006). Race, social capital, and trust in the police. Urban Affairs Review, 41, 358-375.

Martin, S. (1980). Breaking and entering: Police women on patrol. Berkeley, CA: University of California Press.

Martin, S., \& Jurik, N. (2006). Doing justice, doing gender: Women in law and criminal justice occupations. Thousand Oaks, CA: Sage.

McCluskey, J., Mastrofski, S., \& Parks, R. (1999). To acquiesce or rebel: Predicting citizen compliance with police requests. Police Quarterly, 2, 389-416.

McElroy, J., Cosgrove, C. \& Sadd, S. (1993). Community policing: The CPOP in New York. Newbury Park, CA: Sage.

Meng, C. (2009). Prevention of official crime in detention centers based on the case of "duo mao mao". Legal \& Economy, 14, 67-68.

Moon, B. \& Zager, L. (2007). Police officers' attitudes toward citizen support: Focus on individual, organizational and neighborhood characteristic factors. Policing: An International Journal of Police Strategies \& Management, 30, 484-97.

Moore, M., Trojanowicz, R., \& Kelling, G. (1988). Crime and policing. Washington, DC: U.S. Department of Justice.

Murphy, K., \& Cherney, A. (2011). Understanding cooperation with police in a diverse society. British Journal of Criminology, 52, 181-201.

Nee, V. (1996). The emergence of a market society: Changing mechanisms of stratification in China. American Journal of Sociology, 101, 908-949. 
Niederhoffer, A. (1967). Behind the shield: The police in urban society. New York, NY: Doubleday.

Orlik, T. (2011, September 26). Unrest Grows as Economy Booms. The Wall street Journal. Retrieved on September 12, 2015, from http://www.wsj.com/articles/SB1000142405311190370360457658707060050 4108.

Owings, C. (1925). Women Police. Montclair, NJ: Patterson Smith.

Paoline, E. (2003). Taking stock: Toward a richer understanding of police culture. Journal of Criminal Justice, 31, 199-214.

Paoline, E., Myers, S., \& Worden, R. (2000). Police culture, individualism, and community policing: Evidence from two police departments. Justice Quarterly, 17, 575-605.

Paternoster, R., Brame, R., Bachman, R., \& Sherman, L. (1997). Do fair procedures matter? The effect of procedural justice on spouse assault. Law and Society Review, 31, 163-204.

Phillips, S. (2015). The attitudes and goals of police supervisors: Results from a national sample. Police Practice and Research, 5, 364-377.

Pollock, J. (2012). Ethical dilemmas and decisions in criminal justice. Belmont, CA: Wadsworth Cengage Learning.

Poteyeva, M., \& Sun, I. (2009). Gender differences in police officers' attitudes: Assessing current empirical evidence. Journal of Criminal Justice, 37, 512522. 
Qi, S., \& Oberwittler, D. (2009). On the road to the rule of law: Crime, crime control, and public opinion in China. European Journal on Criminal Policy \& Research, 15, 137-157.

Reiner, R. (2010). The politics of the police. New York, NY: Oxford University Press.

Reisig, M. (2007). Procedural justice and community policing: What shapes residents' willingness to participate in crime prevention programs? Policing: A Journal of Policy \& Practice, 1, 356-369.

Reisig, M., \& Parks, R. (2000). Experience, quality of life, and neighborhood context: A hierarchical analysis of satisfaction with police. Justice Quarterly, 17, 607630.

Roberg, R., Crank, J., \& Kuykendall, J. (2000). Police and society. Los Angeles, CA: Roxbury.

Rosenbaum, D. (1988). Community crime prevention: A review and synthesis of the literature. Justice Quarterly, 5, 323-395.

Rowen, H. (2007). When will the Chinese people be free? Journal of Democracy, 18, $38-52$.

Rubinstein, J. (1973). City police. New York, NY: Ballantine.

Scaglion, R., \& Condon, R. (1980). Determinants of attitudes toward city police. Criminology, 17, 485-494.

Schafer, J. (2002). "I'm not against it in theory ...": Global and specific community policing attitudes. Policing: An International Journal of Police Strategies \& Management, 25, 669-686. 
Schuck, A. (2014). Gender differences in policing: Testing hypotheses from the performance and disruption perspectives. Feminist Criminology, 9, 160-185.

Schulz, D. (1995). From social worker to crime fighter. Westport, CT: Praeger.

Shaw, V. (2010). Corrections and punishment in China: Information and analysis. Journal of Contemporary Criminal Justice, 26, 53-71.

Skogan, W. (1978). Citizen satisfaction with police services: Individual and contextual effects. Policy Studies Journal, 7, 469-479.

Skogan, W. (1999). Measuring what matters: Crime, disorder, and fear. In R. Langworthy (Eds.), Measuring what matters: Proceedings from the Policing Research Institute meetings (pp. 37-53). Washington, DC: National Institute of Justice.

Skogan, W., \& Hartnett, S. (1997). Community policing, Chicago style. New York, NY: Oxford University Press.

Skolnick, J., \& Bayley, D. (1988a). Theme and variation in community policing. Crime and Justice, 10, 1-37.

Skolnick, J., \& Bayley, D. (1988b). Community policing: Issues and practices around the world. Washington DC: U.S. Department of Justice, National Institute of Justice, Office of Communication and Research Utilization.

Smith, B., \& Holmes, M. (2003). Community accountability, minority threat, and police brutality: An examination of civil rights criminal complaints. Criminology, 41, 1035-1064. 
Smith, B., \& Holmes, M. (2014). Police use of excessive force in minority communities: A test of the minority threat, place, and community accountability hypotheses. Social Problems, 61, 83-104.

Stone, V., \& Pettigrew, N. (2000). The views of the public on stops and searches. London, UK: Home Office, Policing and Reducing Crime Unit, Research, Development and Statistics Directorate.

Sun, I. (2002). Police officer attitudes toward peers, supervisors, and citizens: A comparison between field training officers and regular officers. American Journal of Criminal Justice, 27, 69-83.

Sun, I. (2003), Police officers' attitudes toward their role and work: A comparison between black and white officers. American Journal of Criminal Justice, 28, 89-108.

Sun, I., \& Chu, D. (2006). Attitudinal differences between Taiwanese and American police officers. Policing: An International Journal of Police Strategies \& Management, 29, 190-210.

Sun, I. \& Chu, D. (2008a). Gender differences in policing: An analysis of Taiwanese officers' attitudes. Police Practice and Research: An International Journal, 9, 431-443.

Sun, I. \& Chu, D. (2008b). A cross-national analysis of female police officers' attitudes in United States and Taiwan. International Criminal Justice Review, $18,5-23$. 
Sun, I., Cretacci, M., Wu, Y., \& Jin, C. (2009). Chinese police cadets' attitudes toward police role and work. Policing: An International Journal of Police Strategies \& Management, 32, 758-780.

Sun, I., Liu, J., \& Farmer, A. (2016). Chinese police supervisors' occupational attitudes: Role orientation, community policing, and job satisfaction. Policing: An International Journal of Police Strategies and Management, forthcoming.

Sun, I. \& Payne, B. (2004). Racial differences in resolving conflicts: a comparison between Black and White police officers. Crime and Delinquency, 50, 516541.

Sun, I., Sobol, J., Cretacci, M., \& Phillips, S. (2010). A comparison of Chinese and the US police cadets' occupational attitudes. Journal of Criminal Justice, 38, 640647.

Sun, I., \& Wu, Y. (2010). Chinese policing in a time of transition, 1978-2008. Journal of Contemporary Criminal Justice, 26, 20-35.

Sun, Y. (2007). An investigation on police job strain. Legal System and Society, 7, $687-687$.

Tanner, M. (2004). China rethinks unrest. Washington Quarterly, 27, 137-156.

Troyer, R. (1989). Chinese thinking about crime and social control. In R. Troyer, J. Clark, \& D. Rojek (Eds.), Social control in the People's Republic of China (pp. 45-56). New York, NY: Praeger.

Tuch, S., \& Weitzer, R. (1997). Trends: Racial differences in attitudes toward the police. Public Opinion Quarterly, 61, 642-663. 
Tyler, T. (2006). Why people obey the law. Princeton, NJ: Princeton University Press.

Tyler, T., \& Wakslak, C. (2004). Profiling and police legitimacy: Procedural justice, attributions of motive, and acceptance of police authority. Criminology, 42, 253-282.

Van Maanen, J. (1974). Working the street: A developmental view of police behavior. In H. Jacob (Eds.), The potential of reform of criminal justice (pp. 83-130). Beverly Hills, CA: Sage.

Walker, S. (1984). "Broken Windows" and fractured history: The use and misuse of history in recent police patrol analysis. Justice Quarterly, 1, 75-90.

Wang, X. (2010). An exploration of the social service role strain, social service role stress and empowerment of frontline police officers in China. Unpublished doctoral dissertation. Hong Kong, City University of Hong Kong.

Wang, X., \& Wong, S. (2012). Police Social Service Work in China: Community Policing with Chinese Characteristics. Asia Pacific Journal of Police and Criminal Justice, 9, 34-54.

Wederman, A. (2004). The intensification of corruption in China. The China Quarterly, 180, 895-921.

Weitzer, R., \& Brunson, R. (2009). Strategic responses to the police among inner-city youth. The Sociological Quarterly, 50, 235-256.

Wilson, J., \& Kelling, G. (2007). Broken Windows: The Police and Community Safety. In E. McLaughlin, J. Muncie \& G. Hughes (Eds), Criminological Perspectives: Essential Readings (pp. 400-411). London, UK: Thousand Oaks. 
Winfree, T., Bartku, G., \& Seibel, G. (1996). Support for community policing versus traditional policing among nonmetropolitan police officers: A survey of four New Mexico police departments. American Journal of Police, 15, 23-50.

Wong, K. (1998). A reflection on police abuse of power in the People's Republic of China. Police Quarterly, 1, 87-112.

Wong, K. (2002). Policing in the People's Republic of China: The road to reform in the 1990s. The British Journal of Criminology, 42, 281-316.

Wong, K. (2009). Chinese policing: History and reform. New York, NY: Peter Lang.

Wooden, K., \& Rogers, C. (2014). Restoring public confidence: Perceptions of community police officers. Police Journal: Theory, Practice, and Principles, 87, 186-194.

Worden, A. (1993). Attitudes of women and men in policing: Testing conventional and contemporary wisdom. Criminology, 31, 203-241.

Worden, R. (1990). A badge and a baccalaureate: Policies, hypotheses, and further evidence. Justice Quarterly, 7, 565-92.

Worden, R. (1996). The Causes of Police Brutality: Theory and Evidence on Police Use of Force. In W. Geller \& H. Toch (Ed.), Police Violence: Understanding and Controlling Police Abuse of Force (pp. 23-51). New Haven, CT: Yale University Press.

Wycoff, M., \& Skogan, W. (1994). The effect of a community policing management style on officers' attitudes. Crime \& Delinquency, 40, 371-383. 
$\mathrm{Xu}$, J. (2009). The robbery of motorcycle taxi drivers (Dake Zai) in China: A lifestyle/routine activity perspective and beyond. British journal of criminology, 49, 491-512.

Yin, W., \& Zhang, M. (2007). Community police affairs on the aspects of harmonious society theory. Beijing, China: Public Security University Press.

Yu, O., \& Zhang, L. (1999). The under-recording of crime by police in China: A case study. Policing: An International Journal of Police Strategies and Management, 22, 252-263.

Zhong, L. (2009). Community policing in China: Old wine in new bottles. Police Practice and Research, 4, 157-169.

Zu, M. (2010). Expression behind the Internet catchphrases: Take "push-ups" and "duo mao mao" as examples. News World, 6, 25-26. 